\title{
DETERMINAN IMBALAN JASA AUDIT: STUDI PADA PERUSAHAAN TERBUKA DI INDONESIA PERIODE 2013-2016
}

\author{
Senny Harindahyani \\ senny.h@staff.ubaya.ac.id \\ Hari Hananto \\ Universitas Surabaya
}

\begin{abstract}
This study investigates the effect of audit tenure, audit rotation, company's complexity, and audit risk on audit fee determined by the auditor from Big-4 and Non Big-4 audit firm. The determination of audit fee is a fundamental process, which can influence the sustainability of the whole audit process. In this study, the sample used is manufacturing companies (basic industry and chemicals, miscellaneous industry, and consumer goods industry) listed on the Indonesia Stock Exchange (IDX) from 2013 to 2016. The result shows that all of the hypothesis are accepted, except for audit risk. In Indonesia, audit risk become a major part of Big-4 audit firm in the process of determining audit fee, while Non Big-4 audit firm is still not considering it as a main part of the determination process. This research also reveals interesting result that CFO as control variable has significant effect on abnormal audit fee, either for Big-4 and Non Big-4.
\end{abstract}

Key words: audit fee; audit tenure; audit rotation; complexity; audit risk.

\begin{abstract}
ABSTRAK
Penelitian ini menginvestigasi dampak dari tenur audit, rotasi audit, kompleksitas perusahaan, dan risiko audit terhadap penentuan imbalan jasa audit yang dilakukan oleh auditor Kantor Akuntan Publik (KAP) Big-4 maupun Non Big-4. Penentuan imbalan jasa audit adalah suatu proses yang fundamental, yang dapat memengaruhi keberlangsungan seluruh proses audit. Dalam penelitian ini, sampel yang digunakan adalah perusahaan manufaktur (industri dasar dan bahan kimia, industri lainnya, dan industri barang konsumen) yang terdaftar di Bursa Efek Indonesia (BEI) dari tahun 2013 sampai dengan 2016. Hasil penelitian menunjukkan bahwa seluruh hipotesis diterima, kecuali variabel risiko audit. Di Indonesia, risiko audit menjadi bagian utama bagi Kantor Akuntan Publik (KAP) Big-4 dalam proses menentukan imbalan jasa audit, namun KAP Non Big-4 masih belum menjadikannya sebagai bagian penting dalam proses penentuan imbalan jasa tersebut. Penelitian ini juga mampu mengungkapkan temuan yang menarik bahwa arus kas operasi (CFO) sebagai variabel kontrol memiliki pengaruh signifikan terhadap imbalan jasa audit abnormal, baik pada KAP Big-4 dan Non Big-4.
\end{abstract}

Kata kunci: imbalan jasa audit; tenur audit; rotasi audit; kompleksitas; risiko audit.

\section{PENDAHULUAN}

Penetapan imbalan jasa audit (Audit Fee) telah menjadi fokus dalam penelitian di bidang audit, seperti yang dilakukan oleh Corbella et al., (2015), de Villiers et al., (2013), Hay (2013), Huang et al., (2009), dan De Angelo (1981). Fenomena yang ditemukan adalah banyaknya faktor yang dapat digunakan oleh suatu Kantor Akuntan Publik
(KAP) dalam menentukan besaran imbalan jasa audit, sehingga hal tersebut dapat menjadi isu yang sensitif mengingat tidak diperkenankannya penetapan yang terlalu tinggi (insentif) atau rendah (diskon). $\mathrm{Ng}$ et al., (2018) mengungkapkan bahwa penetapan imbalan jasa audit merupakan hal yang krusial karena besarannya dapat memengaruhi Kantor Akuntan Publik (KAP) 
dalam mendistribusikan jasa auditnya kepada entitas dan para pemangku kepentingan lainnya secara memadai tanpa mengabaikan unsur indepedensi dalam menyampaikan opini.

KAP di Indonesia diberi kebebasan untuk menentukan besaran tersebut, namun Ikatan Akuntan Publik Indonesia (IAPI), sebagai organisasi profesi, tetap merumuskan aturan yang berkaitan dengan imbalan jasa audit dalam Surat Ketetapan Ketua Umum IAPI No. 24/IAPI/VII/2008 yang telah direvisi menjadi Peraturan Pengurus No. 2 tahun 2016 tentang Penentuan Imbalan Jasa Audit Laporan Keuangan. Pertimbangan utama penetapan imbalan audit dalam peraturan tersebut diantaranya adalah tingkat kompleksitas perusahaan dan besarnya risiko audit, sedangkan komponen lainnya meliputi ruang lingkup pekerjaan, tata kelola perusahaan, ukuran perusahaan, reputasi auditor, dan lain-lain (Rusmanto dan Remond, 2015; El-gammal, 2012; Collings, 2011; Goddard et al., 2006).

Ancaman terhadap profesionalisme dan indepedensi akuntan publik (AP) dalam menetapkan imbalan jasa audit dapat terjadi karena adanya self interest threat dan familiarity threat (Hayes et al., 2014; Collings, 2011). Auditor yang memiliki ikatan keuangan, bisnis, dan keakraban dengan entitas dapat menetapkan jumlah imbalan yang tidak wajar atas pekerjaan audit karena tidak mempertimbangkan komponen-komponen utama atas imbalan jasa audit. Pada akhirnya praktik diskon terhadap imbalan jasa audit (lowballing) maupun perhitungan start-up cost yang tinggi memiliki konsekuensi berupa ancaman terhadap profesionalitas KAP (Grosse et al., 2018; Stanley et al., 2015; Huang et al., 2009).

Penetapan lamanya jangka waktu audit, baik AP maupun KAP yang pernah diatur dalam PMK No. 17/PMK.01/2008 menetapkan bahwa AP dan KAP memiliki masa penugasan selama tiga dan enam tahun berturut-turut. Namun, PP No 20 tahun 2015 tentang Praktik Akuntan Publik memperpanjang masa penugasan tersebut menjadi 5 tahun berturut-turut untuk AP dan tidak ada pembatasan masa penugasan untuk KAP. Perpanjangan masa penugasan mengindikasikan bahwa profesionalisme AP dalam KAP tidak akan terganggu dengan lamanya tenur audit, begitu juga seharusnya dengan indepedensi penetapan imbalan jasa audit. Skema rotasi yang telah ditetapkan dalam peraturan tersebut juga tidak seharusnya memberi dampak yang signifikan terhadap penetapan imbalan jasa audit. Corbella et al. (2015) mengungkapkan bahwa berdasarkan sampel pada perusahaan terbuka di Italia rotasi KAP Big-4 dan Non Big-4 tidak mengalami pengaruh yang signifikan terhadap imbalan jasa audit.

Berbeda dengan tenur audit dan rotasi $\mathrm{AP} / \mathrm{KAP}$, kompleksitas dan risiko audit merupakan komponen utama yang dapat dijadikan sebagai dasar penetapan besarnya imbalan jasa audit. El-gammal (2012) dalam penelitiannya mengungkapkan bahwa tiga variabel utama yang dapat meningkatkan imbalan jasa audit adalah reputasi auditor, kompleksitas perusahaan, dan risiko audit. Kompleksitas perusahaan dikatakan tinggi jika memiliki cabang atau anak perusahaan yang mengakibatkan bertambahnya kebutuhan akan pengawasan dan pelaporan, khususnya di bidang teknologi informasi.

Mazza dan Azzali (2018) mengungkapkan pendapat yang berbeda dari El-gammal (2012), yaitu semakin canggih sistem teknologi informasi yang digunakan akan semakin menurunkan nilai imbalan jasa audit karena AP akan semakin dapat mengandalkan efektifitas sistem pengendalian internal perusahaan. Selain itu, alasan lainnya adalah anak perusahaan juga dapat diaudit oleh KAP yang berbeda dengan induknya, sehingga imbalan jasa audit tidak hanya ditanggung oleh induk perusahaan saja.

Penugasan audit atas laporan keuangan di Indonesia menggunakan Standar Profesional Akuntan Publik (SPAP) yang telah terkonvergensi dengan International Standards on Auditing (ISA), sehingga pendekatan audit yang digunakan adalah pendekatan audit berbasis risiko. Risiko merupakan 
bagian penting dalam pertimbangan pengumpulan bukti audit dengan ketentuan bahwa semakin besar risiko audit, maka semakin banyak pula bukti audit yang harus dikumpulkan (Arens et al., 2017; Hayes et al., 2014). Duellman et al., (2015) mengungkapkan bahwa risiko audit yang tinggi akan menyebabkan auditor bekerja lebih keras, sehingga berdampak pada imbalan jasa audit lebih tinggi. Selain itu, risiko audit yang tinggi juga dapat terjadi karena sifat dari entitas yang diteliti, seperti lembaga penjamin kredit. Leidner dan Lenz (2017) mengungkapkan bahwa entitas keuangan, baik yang go public maupun tidak, memiliki tingkat risiko yang tinggi dan berujung pada besarnya jumlah imbalan jasa audit yang harus ditanggung. Oleh karena itu, baik kompleksitas bisnis auditee dan risiko audit sebaiknya dijadikan dasar dalam mempertimbangkan kalkulasi besarnya imbalan jasa audit di suatu KAP.

Keberadaan imbalan jasa audit menjadi menarik untuk diteliti karena beranekaragamnya pertimbangan yang digunakan oleh KAP untuk menetapkan besaran imbalan jasa audit. Harindahyani (2015) mengungkapkan bahwa auditor juga dapat memiliki risiko untuk terjebak dalam pola berpikir rasional yang subjektif, sehingga penetapan imbalan jasa audit dapat menjadi tidak wajar karena dipengaruhi perhitungan untung rugi. Auditor yang kehilangan profesionalitas dan independensi menjadi ancaman bagi seluruh pengguna laporan keuangan karena opini yang dihasilkan dari penugasan auditnya menjadi tidak andal dan peranannya untuk mengatasi masalah keagenan diantara manajemen (agent) dan pemilik perusahaan (principal) menjadi tidak efektif atau tumpul.

Perumusan masalah berdasarkan penjelasan tersebut adalah penelitian ini akan memberikan bukti empiris mengenai faktorfaktor apa saja yang berpengaruh dan tidak seharusnya berpengaruh terhadap penetapan imbalan jasa audit di Indonesia. Pertanyaan penelitian yang dibangun adalah: (1) Apakah tenur KAP berpengaruh ter- hadap imbalan jasa audit? (2) Apakah rotasi KAP dan AP berpengaruh terhadap imbalan jasa audit? (3) Apakah kompleksitas perusahaan berpengaruh terhadap imbalan jasa audit? (4) Apakah risiko audit berpengaruh terhadap imbalan jasa audit?

Penelitian ini menggunakan sampel perusahaan sektor manufaktur yang terdaftar di Bursa Efek Indonesia (BEI) periode 2013 hingga 2016. Pemilihan sektor manufaktur untuk memfokuskan perhatian pada determinan utama imbalan jasa audit yang digunakan oleh auditor pada perusahaan yang paling banyak mengungkapkan pembayaran beban auditnya.

\section{TINJAUAN TEORETIS \\ Teori Keagenan}

Teori Keagenan memberikan wacana bahwa tindakan manajemen (agent) yang oportunistik dapat menyebabkan permasalahan keagenan yang dapat merugikan pemilik perusahaan (principal) (Jensen dan Meckling, 1976). Teori ini banyak digunakan dalam penelitian di bidang audit karena auditor memiliki peran utama dalam memantau penyajian laporan keuangan oleh pihak manajemen (Safriliana et al., 2018). Hubungan auditor dan auditee adalah hal yang unik, karena dalam penugasannnya auditor adalah pihak independen yang tidak mengakomodasi kepentingan oportunistik pihak manajemen. Auditor membangun serangkaian program dan prosedur audit untuk memberikan opini atas kewajaran laporan keuangan yang disajikan pihak manajemen kepada seluruh pemangku kepentingan.

Perusahaan yang memiliki pengendalian internal yang efektif akan dapat meningkatkan keyakinan auditor mengenai kewajaran penyajian laporan keuangannya. Pengujian atas efektifitas pengendalian internal merupakan bagian yang tidak terpisahkan dalam proses audit dan membawa dampak yang signifikan dalam menilai kemampuan suatu perusahaan untuk mendeteksi, menilai, serta mencegah risiko (Ji et al., 2018; Ebrahim, 2010). Efektivitas pe- 
ngendalian internal di dalam perusahaan akan membantu auditor eksternal menyelesaikan proses audit dengan waktu yang lebih cepat sebagai akibat berkurangnya jumlah pengujian audit (Hassan, 2016). Pada akhirnya, durasi audit yang lebih cepat dapat berdampak material pada penetapan imbalan audit yang lebih rendah oleh KAP.

\section{Imbalan Jasa Audit (Audit Fee)}

KAP merupakan suatu bentuk usaha dalam bidang jasa asurans dan non asurans yang berorientasi laba dengan tetap mempertimbangkan keuntungan dan kerugian. Undang-undang Republik Indonesia No. 5 tahun 2011 tentang Akuntan Publik menyatakan bahwa AP berhak mendapatkan imbalan jasa tanpa syarat dari pihak lain supaya tidak mengganggu berjalannya proses audit.

AP berhak untuk mendapatkan kebebasan dalam rangka menetapkan besarnya imbalan jasa audit yang dianggap sesuai dengan tingkat risiko yang dihadapi, namun terjadinya lowballing tetap harus dihindari (Collings, 2011). Satu argumen lain yang diungkapkan oleh Hayes, Dassen, Schilder, dan Wallage (2014) menyatakan bahwa tidak selalu satu KAP yang menetapkan jumlah imbalan jasa audit lebih rendah dari KAP lain dapat dikategorikan tidak beretika. Oleh karena itu, KAP maupun AP memerlukan pertimbangan yang objektif dalam menentukan imbalan jasa tersebut dan meskipun di Indonesia terdapat peraturan yang disusun oleh organisasi profesi, maka hal tersebut tidak akan serta merta membuat pengimplementasiannya menjadi lebih sederhana. Contohnya, salah satu faktor yang mengakibatkan tingginya imbalan jasa audit di Indonesia adalah jumlah komite audit independen yang banyak (Larasati et al., 2019), padahal keberadaan komite audit independen diharapkan mampu menurunkan tingkat risiko perusahaan. Selain itu, hasil penelitian Sinaga dan Rachmawati (2018) menunjukkan bahwa perusahaan swasta di Indonesia cenderung membayar imbalan jasa audit yang lebih besar dibandingkan dengan Badan Umum Milik Negara (BUMN). Kondisi-kondisi tersebut membuktikan masih terdapat faktor-faktor yang tidak dapat dikendalikan oleh Peraturan Pengurus No. 2 tahun 2016.

\section{Tenur Audit}

Tenur audit merupakan lamanya masa penugasan audit yang dilakukan oleh AP maupun KAP dalam tahun yang berurutan. Ketika perusahaan mengganti auditornya, perhitungan tenur audit akan terhenti dan setelah cooling off period akan dihitung sebagai penugasan audit tahun pertama.

Penelitian Carcello dan Nagy (2004) membuktikan bahwa banyak kecurangan dalam laporan keuangan yang terjadi pada tiga tahun pertama perikatan audit. Geiger dan Raghunandan (2002) menambahkan bahwa auditor cenderung kurang objektif pada tahun pertama penugasan. Hasil penelitian tersebut memberikan kesimpulan bahwa tenur audit yang panjang menjadi lebih baik, walaupun tantangan untuk mempertahankan indepedensi menjadi lebih besar. Namun, hasil penelitian Okoye dan Adeniyi (2016) dan Anastasopoulos dan Anastasopoulos (2012) menyatakan bahwa tenur audit pada akhirnya akan mengakibatkan turunnya kualitas audit, bahkan auditor akan mengalami kecenderungan untuk menjadi lalai terhadap tanggung jawabnya sebagai pihak independen. Oleh karena itu, rotasi auditor menjadi suatu ketetapan yang sudah seharusnya dijalankan. Perspektif berbeda dari Ball et al., (2015) menyatakan bahwa tenur KAP tidak akan membuat auditor menjadi kehilangan indepedensinya, bahkan penelitian yang menggunakan sampel 266 perusahaan yang terdaftar di 2006 ASX atau S \& P Top 500 Australian tersebut menunjukkan pengaruh terhadap peningkatan kualitas audit. Penelitian Krauß dan Zülch (2013) memberi bukti yang lebih konkret mengenai indepedensi auditor dalam mempertahankan kualitas auditnya, baik dalam tenur pendek 
maupun panjang. Terlepas dari pandangan mengenai dampak tenur audit terhadap kualitas audit, pertimbangan tenur audit terhadap imbalan jasa audit membutuhkan analisis lebih jauh. Pada Peraturan Pengurus No. 2 tahun 2016 disebutkan bahwa tenur audit bukanlah prinsip dasar penetapan imbalan jasa audit atas laporan keuangan. Kondisi ini mencerminkan pemikiran mengenai tidak profesionalnya besarnya penetapan imbalan jasa audit oleh AP atau KAP yang mempertimbangkan lama atau tidaknya suatu tenur audit.

Auditor sudah sepantasnya menghindari kondisi yang sifatnya subjektif dalam penentuan imbalan jasa audit demi menjaga independensinya, sehingga tidak terjadi contrast effect. Bhattacharjee et al., (2017) menyatakan terjadinya contrast effect dapat menimbulkan penilaian yang berbeda terhadap kondisi auditee pada saat ini sebagai akibat pengujian audit mengenai objek yang sama di tahun sebelumnya.

\section{Rotasi Audit}

Rotasi audit di Indonesia ada semenjak tahun 2002 dan telah berubah sebanyak tiga kali. Otoritas Jasa Keuangan (OJK) juga mengatur secara khusus penugasan audit dalam Peraturan OJK No. 13/POJK.03/2017 tentang Penggunaan Jasa AP dan KAP dalam Kegiatan Jasa Keuangan dengan ketentuan bahwa AP dapat melakukan audit selama 3 tahun berturut-turut. Rotasi KAP tetap merujuk pada PP No. 20 tahun 2015 yang menetapkan bahwa tidak ada batasan masa audit bagi KAP selama memiliki lebih dari satu partner audit. Perubahan aturan rotasi KAP di Indonesia sudah mengarah pada masa perikatan yang tidak terbatas, sedangkan rotasi AP untuk penugasan audit dalam kegiatan jasa keuangan tetap tiga tahun semenjak tahun 2002.

Imbalan jasa audit juga dapat dikaitkan dengan rotasi AP dan KAP. Pendapat pertama adalah rotasi AP dan KAP dapat memiliki dampak yang signifikan terhadap peningkatan imbalan jasa audit (start-up cost) oleh auditor pengganti (succesor) karena penugasan baru pada umumnya membutuhkan kerja keras dari auditor untuk memahami risiko bisnis perusahaan dan kondisi perusahaan (Cameran et al., 2015; United States General Accounting Office, 2003).

Pendapat kedua adalah auditor pengganti (succesor) yang memiliki perspektif berbeda dengan menerapkan praktik lowballing terhadap imbalan audit ketika terjadi rotasi audit. Banyak hal yang yang diungkapkan oleh penelitian sebelumnya mengenai terjadinya praktik lowballing tersebut. Penetapan imbalan yang terlalu rendah oleh auditor pengganti (succesor) dipandang sebagai investasi dan berdampak pada kecenderungan untuk menjaga hubungan baik dengan perusahaan (Geiger dan Raghunandan, 2002).

Hasil penelitian Johnson dan Keefe (2015) juga mengungkapkan bahwa imbalan jasa audit untuk auditee yang sama pada lingkungan yang kompetitif semakin lama akan semakin tinggi dan pada saat pergantian auditor akan ada diskon atas imbalan tersebut. Pemberian diskon oleh successor dikatakan oleh Mohammadrezaei dan Mohd-saleh (2017) dapat terjadi karena kekuatan penawaran auditor yang masih relatif rendah. Namun, pada akhirnya, dampak rotasi audit terhadap penetapan imbalan jasa audit berdasarkan pendapat kedua dapat menjadi tidak terlihat karena adanya pengalokasian imbalan ke tahuntahun berikutnya.

\section{Kompleksitas}

Hassan dan Hassan (2016) dalam penelitiannya mengenai kompleksitas terhadap Audit Report Lag (ARL) mengungkapkan bahwa perusahaan yang kompleks akan didukung dengan pengendalian internal dan sistem teknologi informasi yang sangat memadai, sehingga dapat mempercepat selesainya proses audit. Kondisi ini dapat terjadi karena pengawasan pihak manajemen dan pihak yang bertanggung jawab 
atas tata kelola (those charged with governance (TCWG)) terhadap proses bisnis, khususnya pembuatan laporan keuangan, menjadi intensif, namun efisien.

Liu et al., (2015) menjelaskan bahwa kompleksitas struktural suatu perusahaan juga ditentukan oleh jumlah anak perusahaan karena hal tersebut menunjukkan strategi diferensiasi yang dilakukan suatu perusahaan. Semakin banyak jumlah anak perusahaan akan menunjukkan semakin kompleksnya suatu perusahaan. Praktik yang terjadi di Indonesia adalah tidak semua anak perusahaan diaudit oleh KAP yang sama dengan induknya (lead auditor), sehingga laporan keuangan konsolidasi teraudit yang disusun oleh auditor utama difinalisasi setelah auditor perusahaan anak melaporkan hasil auditnya kepada lead auditor. Kondisi tersebut dapat mengakibatkan lebih terkonsentrasinya pekerjaan lead auditor, sehingga dapat membantu selesainya proses audit yang lebih tepat waktu.

\section{Risiko Audit}

Pendekatan audit yang digunakan saat ini adalah risk-based approach. SA 315 (IAPI, 2016b) mewajibkan auditor untuk mengidentifikasi dan menilai risiko kesalahan penyajian material pada laporan keuangan perusahaan untuk dijadikan dasar dalam merancang dan mengimplementasikan respons terhadap risiko tersebut.

Risiko audit merupakan suatu risiko yang sulit untuk dihindari oleh auditor karena pengumpulan bukti audit didasarkan pada pengujian yang sebagian besar bersandar pada sampel dan kecurangan juga bukan hal yang mudah untuk dihindari (Arens et al., 2017). Hayes et al. (2014) menjelaskan semakin tinggi risiko audit akan menuntut semakin banyaknya jumlah bukti audit agar pembuatan opini atas laporan keuangan dapat mencapai keyakinan yang memadai. Risiko audit yang tinggi akan membuat auditor melakukan penugasannya dengan lebih seksama dan bekerja dalam durasi penugasan yang lebih lama, sehingga kondisi ini akan membuat pertimbangan penting terhadap imbalan jasa audit.

\section{Pengembangan Hipotesis}

\section{Tenur Audit dan Imbalan Jasa Audit}

Tenur setiap AP dan KAP yang berbeda pada saat melakukan penugasan audit merupakan hal yang wajar. Lamanya tenur audit dapat membuat AP dan KAP menjadi lebih baik dalam memahami kondisi bisnis perusahaan dan menentukan prosedur audit yang sesuai (Al-Thuneibat et al., 2011; Carcello dan Nagy, 2004). Pemahaman terhadap perusahaan pada tahun pertama (initial audit) merupakan tantangan tersendiri bagi auditor daripada pada penugasan berkelanjutan (recurring audit). Ball et al. (2015) membuktikan bahwa tenur KAP yang semakin panjang akan berhubungan dengan semakin meningkatnya kualitas audit dan dampak lainnya biaya mutu akan cenderung menurun. Namun, pada titik tertentu dapat mengakibatkan semakin tidak profesionalnya kinerja auditor dalam penugasan audit (Okoye dan Adeniyi, 2016).

Namun, hal penting yang perlu diperhatikan adalah penentuan imbalan jasa audit harus dilakukan secara profesional dan independen tanpa memperhatikan sudah pernah atau belum pekerjaan audit diberikan pada perusahaan tersebut. IAPI (2016a) pada SA 210 tentang Persetujuan atas Ketentuan Perikatan Audit menyatakan tentang pentingnya prakondisi yang harus selalu dilakukan oleh AP atau KAP disetiap awal penugasannya. Prakondisi akan memberikan gambaran awal mengenai risiko dan kompleksitas yang ada dalam perusahaan.

Peraturan Pengurus No. 2 tahun 2016 yang ditetapkan oleh IAPI tidak memasukkan tenur audit dalam prinsip dasar, melainkan yang diperhitungkan adalah durasi setiap penugasan. Hasil penelitian Jia (2017), Bryan dan Mason (2016), dan Cahan dan Sun (2015) menunjukkan tenur audit AP dan KAP tidak berpengaruh terhadap imbalan jasa audit. Bryan dan Mason (2017) 
bahkan menjelaskan lebih lanjut bahwa tenur audit tidak berpengaruh terhadap imbalan jasa audit meskipun terjadi kompetisi antar top manajemen untuk menduduki posisi sebagai Chief Executive Officer. Dengan demikian, hipotesis pertama penelitian ini adalah:

$\mathrm{H}_{01}$ : Tenure KAP tidak berpengaruh terhadap penetapan imbalan jasa audit

\section{Rotasi Audit dan Imbalan Jasa Audit}

Geiger dan Raghunandan (2002) mengulas pendapat De Angelo (1981) mengenai rotasi audit dan hubungannya terhadap imbalan jasa audit. Rotasi audit dapat menimbulkan terjadinya lowballing imbalan jasa audit, namun selisih kurang tersebut akan dialokasikan pada penetapan imbalan tahun berikutnya. Dengan kata lain, rotasi audit tidak akan berpengaruh terhadap penetapan imbalan jasa audit karena pada akhirnya jumlahnya akan merata di setiap tahun penugasan (Corbella et al., 2015).

Pada dasarnya, rotasi audit sama dengan audit tenur, yaitu tidak terdapat pada prinsip dasar penetapan imbalan jasa audit yang diatur oleh IAPI. Rotasi audit tidak seharusnya menghalangi AP dan KAP untuk mempergunakan pertimbangan profesional dan menjaga indepedensinya untuk menentukan besarnya jasa audit. Tidak seharusnya besaran imbalan jasa terlalu jauh rentangnya antara auditor pendahulu (predecessor) dengan auditor pengganti (successor).

Sebagaimana hasil penelitian Hong dan Hwang (2018), perubahan auditor tidak akan memengaruhi imbalan jasa audit yang ditetapkan. Hal tersebut membuat hipotesis kedua yang diajukan adalah:

$\mathrm{H}_{02 a}$ : Rotasi KAP tidak berpengaruh terhadap penetapan imbalan jasa audit

$\mathrm{H}_{02 \mathrm{~b}}$ : Rotasi AP tidak berpengaruh terhadap penetapan imbalan jasa audit

\section{Kompleksitas dan Imbalan Jasa Audit}

Sesuai prinsip dasar penetapan imbalan jasa audit, kompleksitas merupakan komponen penting yang harus dipertimbangkan dalam menentukan imbalan yang diajukan kepada perusahaan. Kompleksitas transaksi bisnis yang terjadi di perusahaan dapat diidentifikasi dengan keberadaan anak perusahaan dan atau cabang (Liu et al., 2015; Hassan, 2016).

Perusahaan yang kompleks akan memiliki tantangan yang lebih besar dalam proses pengawasannya, namun kehadiran teknologi informasi (TI) merupakan solusi yang efektif bagi perusahaan. Pengendalian internal yang didukung dengan sistem TI yang menyeluruh dapat dijadikan pertimbangan oleh auditor untuk menentukan imbalan jasa audit (Mazza dan Azzali, 2018). Hal tersebut terjadi karena terdapat kendali atas pemisahan tugas dan tanggung jawab, serta kendali atas kepatuhan individu terhadap ketentuan-ketentuan yang dianut perusahaan. Hipotesis ketiga yang diajukan dalam penelitian ini adalah:

$\mathrm{H}_{3}$ : Kompleksitas Bisnis Auditee berpengaruh negatif terhadap penetapan imbalan jasa audit

\section{Risiko Audit dan Imbalan Jasa Audit}

Risiko audit merupakan bagian penting pada era audit berbasis ISA. Risiko merupakan bagian utama dalam proses audit, baik pada proses penilaian risiko sampai dengan proses pelaporan (Arens et al., 2017; Hayes et al., 2014; Collings, 2011).

Duellman et al. (2015) mengungkapkan bahwa risiko audit yang tinggi akan menyebabkan auditor bekerja lebih keras dengan cara mendesain dan mengimplementasikan prosedur audit yang lebih kompleks dalam rangka memenuhi kebutuhan untuk mengumpulkan bukti audit yang tepat dan memadai. Selain itu, risiko audit yang tinggi juga akan melibatkan banyaknya jumlah auditor yang terlibat (Kusharyanti, 2013). Auditor yang dipilih 
tentunya juga diperhatikan levelnya atau dengan kata lain kompetensinya. Oleh karena itu, hipotesis keempat penelitian ini adalah:

$\mathrm{H}_{4}$ : Risiko Audit pengaruh positif terhadap penetapan Fee Audit

\section{METODE PENELITIAN}

\section{Rerangka Pemikiran dan Jenis Riset Jenis dan Sumber Data}

Penelitian ini dilakukan dengan menggunakan data sekunder, yaitu laporan tahunan dan laporan keuangan perusahaan terbuka yang terdaftar di Bursa Efek Indonesia (BEI) dan dapat dilihat di-websitenya. Variabel dependen yang digunakan dalam penelitian utama adalah imbalan jasa audit (totrevscaled), sedangkan variable independennya meliputi tenur audit (TenKAP), rotasi audit (RKAP (rotasi Kantor Akuntan Publik) dan RAP (rotasi Akuntan Publik)), kompleksitas (Comp), serta risiko audit (ARisk). Selain itu, permodelan ini juga menggunakan variabel kontrol yang terdiri dari arus kas operasi (CFO), leverage (Lev), return on assets (ROA), ukuran perusahaan (Size), dan pertumbuhan penjualan (SALESGR).

Variabel dependen berikutnya dalam penelitian ini adalah imbalan jasa audit abnormal (abnfees) dengan menggunakan variable independen dan kontrol yang sama. Variabel dependen ini merupakan pengujian tambahan untuk mengetahui variabel independen mana yang memiliki hasil kuat atau sama dengan hasil permodelan utama.

\section{Populasi dan Metode Sampling}

Populasi penelitian adalah seluruh perusahaan yang terdapat di BEI periode 2013-2016. Metode pengambilan sampel yang digunakan adalah non probability sampling purposive judgemental dengan kriteria, sebagai berikut: (1) Seluruh perusahaan manufaktur; (2) Perusahaan memiliki laporan akhir tahun per 31 Desember; (3) Mata uang yang digunakan dalam laporan keuangannya adalah Rupiah.

\section{Model Penelitian}

Model penelitian berikut ini digunakan untuk menguji faktor-faktor apa saja yang memengaruhi penetapan imbalan jasa audit. Model pengujian pertama menggunakan imbalan jasa audit (totrevscaled) untuk seluruh sampel (full sample), sedangkan model kedua dan ketiga merupakan pecah sampel untuk mengetahui dampak seluruh faktor tersebut pada KAP Big-4 dan Non Big4. KAP Big-4 terdiri dari Deloitte Touche Tohmatsu (Deloitte), Pricewaterhouse Coopers (PwC), Ernst dan Young (EY), dan Klynveld Peat Marwick Goerdeler (KPMG), sedangkan KAP Non Big-4 adalah semua KAP selain kelompok Big-4.

Pengklasifikasian KAP Big-4 dan Non Big-4 masih relevan mengingat perbedaan kualitas audit dua kelompok tersebut masih diteliti sampai dengan saat ini. Habib et al., (2019) membuktikan bahwa beban kerja AP meningkatkan biaya modal ekuitas perusahaan, terutama pada perusahaan yang menggunakan KAP Non Big-4. Selain itu, beban kerja juga memperpanjang penyelesaian waktu audit, terutama untuk auditee KAP Non Big-4 (Wan Hussin et al., 2018).

Permodelan utama dalam penelitian ini terdiri dari Pemodelan 1, 2, dan 3. Permodelan 1 adalah permodelan utama yang digunakan untuk menjawab hipotesis yang diajukan pada penelitian ini. Permodelan 2 digunakan untuk mendapatkan bukti pengaruh seluruh variabel independen terhadap variabel dependen pada KAP Big-4, sedangkan Permodelan 3 pada KAP Non Big-4 saja.

Pecah sampel ini diperlukan untuk menambahkan hasil yang lebih detail mengenai peran variabel independen tersebut. Keterangan dan simbol dari permodelan dapat dilihat pada Tabel 1.

Permodelan 1 (full sample):

$$
\begin{aligned}
\text { totrevscaled }_{\mathrm{i}, \mathrm{t}} & =\beta_{0}+\beta_{1} \text { TenKAP }_{\mathrm{i}, \mathrm{t}} \\
& +\beta_{2} \text { RKAP }_{\mathrm{i}, \mathrm{t}}+\beta_{3} \operatorname{Comp}_{\mathrm{i}, \mathrm{t}} \\
& +\beta_{4} \text { ARisk }_{\mathrm{i}, \mathrm{t}}+\beta_{5} \text { CFO }_{\mathrm{i}, \mathrm{t}} \\
& +\beta_{6} \text { Lev }_{\mathrm{i}, \mathrm{t}}+\beta_{7} \text { ROA }_{\mathrm{i}, \mathrm{t}}+\epsilon
\end{aligned}
$$


Permodelan 2 (Big-4):

$$
\begin{aligned}
\text { totrevscaled }_{\mathrm{i}, \mathrm{t}} & =\beta_{0}+\beta_{1} \text { TenKAP }_{\mathrm{i}, \mathrm{t}} \\
& +\beta_{2} \text { RAP }_{\mathrm{i}, \mathrm{t}}+\beta_{3} \operatorname{Comp}_{\mathrm{i}, \mathrm{t}} \\
& +\beta_{4} \text { ARisk }_{\mathrm{i}, \mathrm{t}}+\beta_{5} \operatorname{Size}_{\mathrm{i}, \mathrm{t}} \\
& +\beta_{6} \text { CFO }_{\mathrm{i}, \mathrm{t}}+\beta_{7} \operatorname{Lev}_{\mathrm{i}, \mathrm{t}} \\
& +\beta_{8} \operatorname{SALESGR}_{\mathrm{i}, \mathrm{t}}+\beta_{9} R O \mathrm{~A}_{\mathrm{i}, \mathrm{t}} \\
& +\epsilon
\end{aligned}
$$

Permodelan 3 (Non Big-4):

$$
\begin{aligned}
\text { totrevscaled }_{\mathrm{i}, \mathrm{t}} & =\beta_{0}+\beta_{1} \text { TenKAP }_{\mathrm{i}, \mathrm{t}} \\
& +\beta_{2} \text { RAP }_{\mathrm{i}, \mathrm{t}}+\beta_{3} \operatorname{Comp}_{\mathrm{i}, \mathrm{t}} \\
& +\beta_{4} \text { ARisk }_{\mathrm{i}, \mathrm{t}}+\beta_{5} L e v_{\mathrm{i}, \mathrm{t}} \\
& +\beta_{6} \text { SALESGR }_{\mathrm{i}, \mathrm{t}}+\beta_{7} \text { ROA }_{\mathrm{i}, \mathrm{t}} \\
& +\epsilon
\end{aligned}
$$

Penelitian ini juga menggunakan permodelan tambahan untuk menguji kembali peran keseluruh variabel independen terhadap variabel dependen yang menggunakan proksi berbeda, yaitu imbalan jasa audit abnormal. Permodelan tambahan menggunakan variabel dependen imbalan jasa audit abnormal dengan menggunakan Model Hope (2009) yang dimodifikasi oleh Corbella et al. (2015), sebagai berikut:

$$
\begin{aligned}
\text { TOTFEE }_{\mathrm{i}, \mathrm{t}}= & \beta_{0}+\beta_{1} \text { BIG }_{\mathrm{i}, \mathrm{t}}+\beta_{2} \text { Size }_{\mathrm{i}, \mathrm{t}} \\
& +\beta_{3} \operatorname{LOSS}_{\mathrm{i}, \mathrm{t}}+\beta_{4} \operatorname{Lev}_{\mathrm{i}, \mathrm{t}} \\
& +\beta_{5} \operatorname{ROA}_{\mathrm{i}, \mathrm{t}}+\epsilon
\end{aligned}
$$

Imbalan jasa audit abnormal merupakan nilai residu dari hasil regresi di atas dengan cara menghitung TOTFEE yang didapat dari membagi imbalan jasa audit suatu perusahaan dengan total asetnya.

Permodelan tambahan terdiri dari Permodelan 4, 5, dan 6. Permodelan 4 seperti pada Permodelan 1 menggunakan full sample, sedangkan Permodelan 5 dan 6 menggunakan pecah sampel berdasarkan jenis KAP, seperti pada Permodelan 5 dan 6. Permodelan 4 (full sample):

$$
\begin{aligned}
\text { abnfees }_{\mathrm{i}, \mathrm{t}}= & \beta_{0} \\
& +\beta_{1} \text { TenKAP }_{\mathrm{i}, \mathrm{t}}+\beta_{2} \text { RKAP }_{\mathrm{i}, \mathrm{t}} \\
& +\beta_{3} \operatorname{Comp}_{\mathrm{i}, \mathrm{t}}+\beta_{4} \text { ARiSk }_{\mathrm{i}, \mathrm{t}} \\
& +\beta_{5} \operatorname{Size}_{\mathrm{i}, \mathrm{t}}+\beta_{6} \text { CFO }_{\mathrm{i}, \mathrm{t}} \\
& +\beta_{7} \text { Lev }_{\mathrm{i}, \mathrm{t}}+\beta_{8} \text { SALESGR }_{\mathrm{i}, \mathrm{t}} \\
& +\epsilon
\end{aligned}
$$

Permodelan 5 (Big-4):

$$
\begin{aligned}
\text { abnfees }_{\mathrm{i}, \mathrm{t}}= & \beta_{0} \\
& +\beta_{1} \text { TenKAP }_{\mathrm{i}, \mathrm{t}}+\beta_{2} \text { RAP }_{\mathrm{i}, \mathrm{t}} \\
& +\beta_{3} \operatorname{Comp}_{\mathrm{i}, \mathrm{t}}+\beta_{4} \text { ARisk }_{\mathrm{i}, \mathrm{t}} \\
& +\beta_{5} \text { Size }_{\mathrm{i}, \mathrm{t}}+\beta_{6} \text { CFO }_{\mathrm{i}, \mathrm{t}} \\
& +\beta_{7} \operatorname{Lev}_{\mathrm{i}, \mathrm{t}}+\beta_{8} \text { SALESGR }_{\mathrm{i}, \mathrm{t}} \\
& +\epsilon
\end{aligned}
$$

Permodelan 6 (Non Big-4):

$$
\begin{aligned}
\text { abnfees }_{\mathrm{i}, \mathrm{t}}= & \beta_{0} \\
& +\beta_{1} \text { TenKAP }_{\mathrm{i}, \mathrm{t}}+\beta_{2} \text { RAP }_{\mathrm{i}, \mathrm{t}} \\
& +\beta_{3} \operatorname{Comp}_{\mathrm{i}, \mathrm{t}}+\beta_{4} \text { ARis }_{\mathrm{i}, \mathrm{t}} \\
& +\beta_{5} \text { Size }_{\mathrm{i}, \mathrm{t}}+\beta_{6} \text { CFO }_{\mathrm{i}, \mathrm{t}} \\
& +\beta_{7} \operatorname{Lev}_{\mathrm{i}, \mathrm{t}}+\beta_{8} R O A_{\mathrm{i}, \mathrm{t}}+\epsilon
\end{aligned}
$$

Berdasarkan hipotesis yang dibangun dan persamaan yang terdiri dari ketiga permodelan utama tersebut, kerangka konseptual dapat diilustrasikan sebagai berikut:

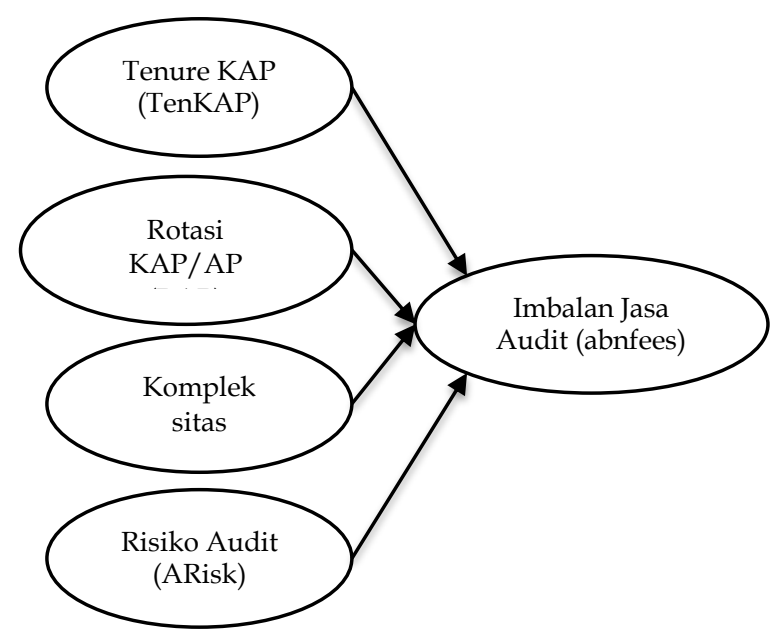

Variabel Kontrol:

Size, Cash Flow from Operations (CFO),

Leverage, Pertumbuhan Penjualan, Return

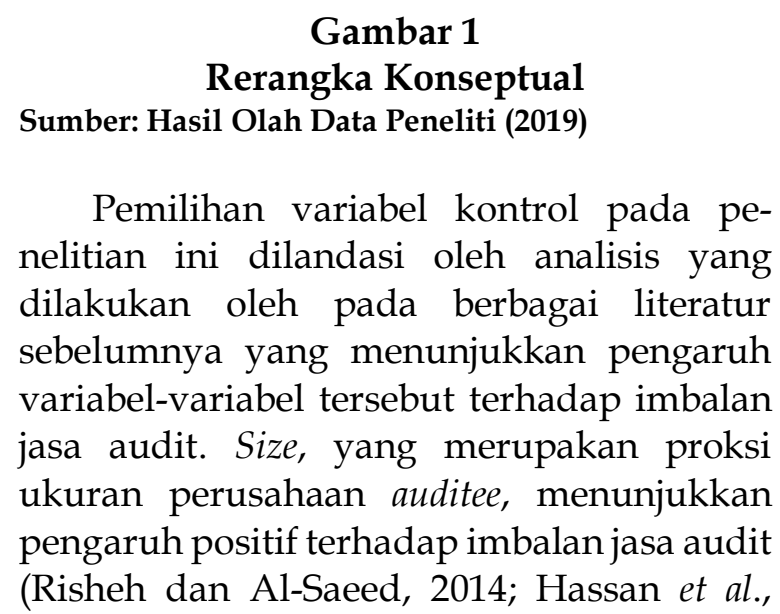


2014). Artinya, semakin besar ukuran perusahaan akan berpengaruh terhadap semakin tingginya penetapan imbalan jasa audit yang ditetapkan. CFO dihadirkan sebagai variabel kontrol pada penelitian ini dengan berdasarkan permodelan Corbella $e t$ al. (2015).

Leverage merupakan salah satu ukuran risiko operasional yang memiliki pengaruh signifikan positif terhadap imbalan jasa audit (Risheh dan Al-Saeed, 2014). Berdasarkan penelitian Keane et al., (2012), SALESGR (pertumbuhan penjualan) mengakibatkan meningkatnya imbalan jasa audit. ROA sebagaimana penelitian Huang et al., (2014) dan Charles et al., (2010) diharapkan memiliki pengaruh negatif terhadap imbalan jasa audit.

\section{Data dan Metode Pengumpulan Data}

Penelitian ini menggunakan sampel seluruh perusahaan manufaktur yang terdaftar di BEI pada tahun 2013-2016.

\section{Teknis Analisis Data}

Prosedur analisis data yang digunakan adalah regresi linear berganda dengan menggunakan data cross section. Setelah melakukan Uji Asumsi Klasik, hasil penelitian akan melihat hasil Uji F untuk melihat goodness of fit dari permodelan yang dibangun dan juga melihat hasil Uji t untuk melihat pengaruh masing-masing variabel independen terhadap variabel dependen.

Analisis dilakukan pada permodelan 1, 2, dan 3 untuk menjawab seluruh hipotesis penelitian. Selanjutnya, analisis tambahan dilakukan dengan menggunakan permodelan 4,5, dan 6 dengan menggunakan variabel dependen imbalan jasa audit abnormal.

Tabel 1

\section{Definisi Operasional Variabel}

\begin{tabular}{|c|c|}
\hline Totrevscaled dan TOTFEE & $\begin{array}{l}\text { Imbalan jasa audit dihitung dari total biaya audit yang dibayarkan } \\
\text { kepada auditor dibagi dengan total penjualan oleh perusahaan i pada } \\
\text { periode t (Corbella et al., 2015) }\end{array}$ \\
\hline \multicolumn{2}{|l|}{ Variabel Independen } \\
\hline TenKAP & $\begin{array}{l}\text { Tenur KAP adalah lamanya masa penugasan audit secara berturut- } \\
\text { turut oleh KAP untuk perusahaan yang sama (Bryan dan Mason, } \\
\text { 2017; Jia, 2017) }\end{array}$ \\
\hline RKAP atau RAP & $\begin{array}{l}\text { Rotasi KAP atau AP merupakan variabel biner yang menunjukkan } \\
\text { angka sama dengan } 1 \text { jika perusahaan i pada periode } t \text { melakukan } \\
\text { rotasi auditor (KAP atau AP) dan sama dengan } 0 \text { jika sebaliknya } \\
\text { (Mohammadrezaei dan Mohd-saleh, 2017). }\end{array}$ \\
\hline Comp & $\begin{array}{l}\text { Kompleksitas merupakan variabel biner yang menunjukkan angka } \\
\text { sama dengan } 1 \text { jika perusahaan i pada periode } t \text { memiliki anak } \\
\text { perusahaan dan/ atau cabang dan sama dengan } 0 \text { jika tidak } \\
\text { memilikinva (Hassan, 2016). }\end{array}$ \\
\hline ARisk & $\begin{array}{l}\text { Risiko Audit dihitung dari penjumlahan piutang usaha dan } \\
\text { persediaan dibagi dengan total aset (Jubb et al., 1996). }\end{array}$ \\
\hline \multicolumn{2}{|l|}{ Variabel Kontrol } \\
\hline Size & $\begin{array}{l}\text { ukuran perusahaan yang dihitung dari logaritma natural total aset } \\
\text { (Jia, 2017). }\end{array}$ \\
\hline $\mathrm{CFO}$ & $\begin{array}{l}\text { Cash Flow from Operations merupakan arus kas operasional } \\
\text { perusahaan (Corbella et al., 2015). }\end{array}$ \\
\hline Lev & Leverage dihitung dari total utang dibagi total aset (Xie et al., 2010). \\
\hline SALESGR & $\begin{array}{l}\text { Pertumbuhan Penjualan dihitung dari hasil penjualan bersih } \\
\text { perusahaan i pada periode } t \text { dikurangi periode } t-1 \text { dibagi dengan } \\
\text { periode } t-1 \text { (Corbella et al., 2015). }\end{array}$ \\
\hline
\end{tabular}




\begin{tabular}{|c|c|}
\hline ROA & $\begin{array}{l}\text { Return on Assets dihitung dari net income dibagi total aset (Yatim et al., } \\
\text { 2006). }\end{array}$ \\
\hline BIG & $\begin{array}{l}\text { BIG adalah variabel biner yang menunjukkan angka sama dengan } 1 \\
\text { jika perusahaan diaudit oleh Big-4 dan sama dengan } 0 \text { jika diaudit } \\
\text { oleh yang lainnya. }\end{array}$ \\
\hline LOSS & $\begin{array}{l}\text { Kerugian merupakan variabel biner yang menunjukkan angka sama } \\
\text { dengan } 1 \text { jika perusahaan mengalami kerugian dan sama dengan } 0 \\
\text { jika yang lainnya. }\end{array}$ \\
\hline \multicolumn{2}{|r|}{ J } \\
\hline $\begin{array}{l}\boldsymbol{\beta}_{\mathbf{0}} \\
\boldsymbol{\beta}_{\mathbf{1}}-\boldsymbol{\beta}_{\mathbf{9}} \\
\in\end{array}$ & $\begin{array}{l}\text { Konstanta atau intercept. } \\
\text { Koefisien Regresi } \\
\text { Error }\end{array}$ \\
\hline
\end{tabular}

\section{ANALISIS DAN PEMBAHASAN}

Hasil Seleksi Sampel

Hasil regresi selama 4 tahun dengan tahun pengamatan selama 2013-2016 terhadap perusahaan manufaktur di Indonesia yang telah disesuaikan dengan kriteria penelitian mendapatkan rincian sampel untuk setiap pemodelannya, yaitu mulai dari permodelan 1 sampai 6 , secara berturutturut adalah 134, 52, 91, 139, 49, 90 tahun perusahaan sebagaimana dapat dilihat pada Tabel 2 dan Tabel 4.

Tabel 2

Statistik Deskriptif Determinan Imbalan Jasa Audit

\begin{tabular}{|c|c|c|c|c|c|}
\hline \multicolumn{6}{|c|}{ Panel A: Seluruh Sampel } \\
\hline Variabel & Jumlah & Mean & Min & Max & Deviasi Standar \\
\hline Totrevscaled & 134 & 0,0003286 & 0,00004 & 0,00123 & 0,00026518 \\
\hline TKAP & 134 & 4,86 & 1 & 15 & 3,086 \\
\hline Arisk & 134 & 0,485009 & 0,0319 & 17,1100 & 1,4551653 \\
\hline CFO & 134 & 0,0709 & $-0,64$ & 0,52 & 0,13352 \\
\hline Lev & 134 & 0,4346 & 0,07 & 2,73 & 0,28258 \\
\hline ROA & 134 & 0,0650 & $-0,15$ & 0,43 & 0,08673 \\
\hline Variabel & \multicolumn{2}{|c|}{ Frekuensi Nilai 1} & \multicolumn{2}{|c|}{ Frekuensi Nilai 0} & \\
\hline RKAP & \multicolumn{2}{|c|}{$11,19 \%$} & \multicolumn{2}{|c|}{$88,81 \%$} & \\
\hline Comp & \multicolumn{2}{|c|}{$68,66 \%$} & \multicolumn{2}{|c|}{$31,34 \%$} & \\
\hline
\end{tabular}

\begin{tabular}{|c|c|c|c|c|c|}
\hline \multicolumn{6}{|c|}{ Panel B: Perusahaan yang Diaudit KAP Big-4 } \\
\hline Variabel & Jumlah & Mean & Min & $\operatorname{Max}$ & Deviasi Standar \\
\hline Totrevscaled & 52 & ,0009627 & ,00004 & 02771 & ,00379608 \\
\hline TKAP & 52 & 6,98 & 1 & 15 & 3,245 \\
\hline Arisk & 52 & ,3352 & ,03 & 61 & 14009 \\
\hline SIZE & 52 & 29,1382 & 27,19 & 32,15 & 1,40680 \\
\hline $\mathrm{CFO}$ & 52 & 1377 &,- 13 & 1,26 & 18362 \\
\hline Lev & 52 & 4744 & ,13 & 6,87 & ,91893 \\
\hline SALESGR & 52 & ,0977 &,- 79 & 1,34 & 28782 \\
\hline $\mathrm{ROA}$ & 52 & 1112 &,- 15 & ,43 & 10649 \\
\hline Variabel & \multicolumn{2}{|c|}{ Frekuensi Nilai 1} & \multicolumn{2}{|c|}{ Frekuensi Nilai 0} & \\
\hline RAP & \multicolumn{2}{|c|}{$50,00 \%$} & \multicolumn{2}{|c|}{$50,00 \%$} & \\
\hline Comp & \multicolumn{2}{|c|}{$71,15 \%$} & \multicolumn{2}{|c|}{$28,85 \%$} & \\
\hline
\end{tabular}

Panel C: Perusahaan yang Diaudit KAP Non Big-4

\begin{tabular}{llllll}
\hline Variabel & Jumlah & Mean & Min & Max & Deviasi Standar \\
\hline Totrevscaled & 91 &, 0003358 &, 00005 &, 00172 &, 00032946 \\
TKAP & 91 & 3,71 & 1 & 10 & 2,182
\end{tabular}




\begin{tabular}{|c|c|c|c|c|c|}
\hline Arisk & 91 & ,5551 & ,06 & 17,11 & 1,76239 \\
\hline Lev & 91 & ,4676 & ,07 & 2,73 & 31913 \\
\hline SALESGR & 91 & 1806 &,- 35 & 6,05 & 89585 \\
\hline ROA & 91 & ,0375 &,- 14 & ,17 & 06142 \\
\hline Variabel & & Frekuensi Nilai 1 & & Nilai 0 & \\
\hline RAP & & $48,35 \%$ & & & \\
\hline Comp & & $65,93 \%$ & & & \\
\hline
\end{tabular}

Sumber: Hasil Olah Data Peneliti (2019)

\section{Analisis Statistik Deskriptif}

Rata-rata jumlah imbalan jasa audit perusahaan manufaktur di Indonesia adalah sebesar $0,033 \%$ dari pendapatannya, sedangkan rata-rata imbalan jasa audit KAP Big-4 sebesar 0,096\% dari pendapatannya atau 0,063\% lebih besar dari KAP Non Big-4. Kondisi menunjukkan adanya indikasi imbalan jasa premium yang diterima oleh KAP Big-4. Tenur KAP paling lama sebesar 15 tahun diberikan oleh KAP Big-4 dan secara rata-rata perusahaan yang diaudit oleh Big-4 dapat dikatakan lebih loyal karena rata-rata tenur auditnya mencapai tujuh tahun dibandingkan dengan Non Big-4 yang rata-ratanya mencapai empat tahun. Kedua kondisi ini mengindikasikan bahwa auditee bersedia untuk membayar lebih mahal jasa audit yang diberikan oleh KAP Big-4 karena kualitas audit yang diberikan oleh KAP tersebut dianggap lebih baik dari pada KAP Non Big-4.

Prosentase rotasi AP, baik Big-4 maupun Non Big-4, lebih sering terjadi daripada rotasi KAP. Hal ini sesuai dengan ketentuan PP No. 20 tahun 2015 yang menyatakan bahwa AP masih memiliki kewajiban untuk berotasi, sedangkan KAP dapat tidak berotasi. Jumlah perusahaan manufaktur di Indonesia yang memiliki anak perusahaan dan atau cabang adalah sebesar $68,66 \%$. Pada Tabel 2, kompleksitas klien KAP Big-4 sebesar $71,15 \%$ atau lebih tinggi sebesar $5,22 \%$ dari KAP Non Big-4 yang sebesar $65,93 \%$. Kondisi ini juga memperkuat analisis deskriptif sebelumnya yang menyatakan bahwa KAP Big-4 memiliki rata-rata imbalan jasa yang lebih tinggi karena banyaknya entitas yang diaudit dengan tingkat kompleksitas yang tinggi dapat mengakibatkan auditor untuk memiliki daya tawar yang tinggi dalam penentuan imbalan jasa auditnya.

\section{Hasil Regresi}

Hasil pengujian permodelan 1 pada Tabel 3 menunjukkan bahwa permodelan tersebut terbukti signifikan pada tingkat keyakinan 98,5\%, sehingga dapat disimpulkan seluruh variabel independen secara serempak memiliki pengaruh yang signifikan terhadap imbalan jasa audit.

Hasil permodelan 2 dan 3 juga terbukti signifikan pada tingkat keyakinan 99\%, artinya seluruh variabel independen secara serempak dapat memengaruhi penentuan imbalan jasa audit, baik oleh KAP Big-4 maupun Non Big-4. Hasil regresi Permodelan 1 menunjukkan bahwa variabel tenur audit dan rotasi KAP tidak berpengaruh signifikan terhadap penetapan imbalan jasa audit oleh KAP terhadap perusahaan manufaktur oleh KAP di Indonesia. Temuan ini sesuai dengan hasil penelitian Jia (2017); Bryan dan Mason (2016); Cahan dan Sun (2015) yang juga tidak menemukan adanya pengaruh tenur auditor terhadap imbalan jasa audit. Selanjutnya, hasil pecah sampel melalui pendekatan Big4 maupun Non Big-4, yang menggunakan variabel tenur KAP dan rotasi AP, juga memperkuat hasil dari permodelan pertama, sehingga dapat disimpulkan bahwa $\mathbf{H}_{01}$, $\mathbf{H}_{02 a}$, dan $\mathbf{H}_{02 \mathrm{~b}}$ diterima.

Tenur KAP bukan merupakan pertimbangan utama dalam menghitung besarnya nilai imbalan yang pantas dari auditee yang mana hasil penelitian ini sekaligus membuktikan bahwa auditor perusahaan manufaktur di Indonesia telah menjalankan 
indepedensinya dan mempergunakan pertimbangan objektifnya. Pada dasarnya, KAP akan lebih mengenal perusahaan jika telah melakukan penugasan audit berulang dan semakin lama mengaudit perusahaan yang sama familiarity threat sangat memungkinkan untuk terjadi. Namun, kondisi tersebut tidak boleh menjadi alasan bagi KAP untuk mempermainkan perhitungan nilai imbalan jasa bagi kliennya, terutama dalam konteks lowballing imbalan jasa audit (Collings, 2011). Auditor harus tetap mempertimbangkan determinan penting dalam menghitung imbalan jasa auditnya tanpa menghadirkan perasaan empati yang memengaruhi pertimbangan logisnya dalam mengambil keputusan. Rotasi auditor juga terbukti tidak memengaruhi penetapan imbalan jasa audit. Kondisi tingginya start-up cost atas imbalan jasa audit dapat terjadi di awal penugasan audit (United States General Accounting Office,
2003) dan ketika hal tersebut terjadi, penentuan nilai imbalan menjadi tidak profesional karena hanya mempertimbangkan masalah keuntungan tanpa menganalisis risiko secara memadai. Namun, penetapan imbalan jasa audit bagi perusahaan manufaktur di Indonesia tidak menggunakan rotasi KAP maupun AP sebagai pertimbangannya. Situasi ini memberikan bukti bahwa penentuan imbalan jasa audit pada perusahaan manufaktur di Indonesia menunjukkan profesionalitas successor untuk melakukan perhitungan secara logis.

Rotasi tidak dipandang sebagai suatu celah untuk mengambil keuntungan irasional atau melakukan praktik lowballing. Pendapat Corbella et al. (2015) mengenai alokasi imbalan jasa audit yang berasal dari awal tahun penugasan menjadi tidak terbukti karena dalam hal ini audit tenur pun tidak memiliki pengaruh yang signifikan.

Tabel 3

Hasil Regresi Determinan Imbalan Jasa Audit

\begin{tabular}{llll}
\hline \hline Variabel & Seluruh Sampel & KAP Big-4 & KAP Non Big-4 \\
\hline TKAP & $1,072 \mathrm{E}-5$ & $-3,578 \mathrm{E}-6$ & $1,506 \mathrm{E}-5$ \\
RKAP & $6,176 \mathrm{E}-5$ & - & - \\
RAP & - & 0,000 & $-5,813 \mathrm{E}-6$ \\
Comp & $-0,000^{* *}$ & $-0,001^{*}$ & $-0,000^{*}$ \\
Arisk & $-2,614 \mathrm{E}-5$ & $0,010^{* * *}$ & $-1,813 \mathrm{E}-5$ \\
Size & - & $3,958 \mathrm{E}-5$ & - \\
CFO & 0,000 & $0,021^{* * *}$ & - \\
Lev & $0,000^{* * *}$ & 0,000 &, $000^{* * *}$ \\
SALESGR & - & $-0,001$ & $9,853 \mathrm{E}-5^{* * *}$ \\
ROA & $-7,308 \mathrm{E}-5$ & $-0,010^{* * *}$ &,$- 002^{* * *}$ \\
Konstanta & 0,000 & $-0,004$ & 0,001 \\
Sampel & 134 & 52 & 91 \\
Prob > chi2 & 0,015 & 0,000 & 0,000 \\
Adj R & 0,079 & 0,902 & 0,256 \\
\hline
\end{tabular}

Keterangan Tabel:

TKAP = Tenur KAP; lamanya masa penugasan audit oleh KAP, RKAP/ RAP = Rotasi KAP atau rotasi AP; bernilai 1 jika pada tahun pengamatan melakukan rotasi dan 0 jika sebaliknya, Comp = kompleksitas perusahaan; bernilai 1 jika perusahaan memiliki anak atau cabang dan 0 jika sebaliknya; Arisk = risiko audit; penjumlah piutang usaha dan persediaan yang dibagi dengan total aset, Size $=$ ukuran perusahaan; logaritma natural dari total aset perusahaan, $\mathbf{C F O}=$ arus kas operasional perusahaan, Lev = leverage perusahaan; total utang dibagi total aset perusahaan, SALESGR = pertumbuhan penjualan perusahaan; selisih penjualan perusahaan dengan tahun sebelumnynya dibagi penjualan tahun sebelumnya, $\mathbf{R O A}=$ rasio pengembalian aset perusahaan; net income dibagi dengan total aset perusahaan. 
Kompleksitas berpengaruh secara signifikan negatif terhadap imbalan jasa audit, sehingga $\mathrm{H}_{3}$ diterima, artinya semakin tinggi kompleksitas suatu perusahaan semakin rendah imbalan jasa auditnya. Hal ini sejalan dengan hasil penelitian Mazza dan Azzali (2018) yang mengungkapkan bahwa TI merupakan bagian yang tidak terpisahkan bagi perusahaan terbuka.

Perusahaan terbuka yang memiliki banyak anak perusahaan dan cabang akan semakin berusaha untuk mengintegrasikan sistem informasinya. Integrasi sistem sangat diperlukan untuk memantau berjalannya proses operasional, terutama yang menyangkut implementasi pengendalian internal, pelaporan keuangan yang memadai, dan kepatuhan terhadap hukum serta peraturan yang berlaku.

Pendapat lain yang dapat disampaikan adalah proses penentuan imbalan jasa audit di Indonesia hanya mencakup lingkup pekerjaan audit yang dilakukan oleh KAP yang bersangkutan. Jika dalam pelaksanaannya KAP yang sama melakukan audit atas laporan keuangan konsolidasi dan seluruh laporan keuangan individu anggota korporasi, pembayaran imbalan jasa audit oleh induk perusahaan dan anak perusahaan berhak untuk diterima seluruhnya oleh KAP tersebut. Namun, jika terdapat anak perusahaan yang tidak diaudit oleh KAP yang sama dengan induk perusahaannya, perusahaan anak tersebut akan menanggung sendiri pembayaran beban jasa auditnya. Hal tersebut mengakibatkan total imbalan jasa audit yang ditanggung oleh induk akan menjadi lebih rendah dari pada kondisi pertama.

Audit atas laporan keuangan yang dilakukan terpisah oleh KAP atau AP pada suatu korporasi bukanlah menjadi suatu isu baru di Indonesia. Penunjukkan auditor yang berbeda tersebut biasanya menggunakan pertimbangan efisiensi imbalan jasa audit. Standar audit juga memperbolehkan kondisi tersebut, selama lead auditor tetap menjadi pihak yang bertanggung jawab terhadap perlaksanaan audit terhadap suatu korporasi secara menyeluruh. Artinya, pengendalian terhadap proses audit, yang berkaitan dengan program dan prosedur audit, oleh auditor anak perusahaan tetap dikoordinasi oleh lead auditor.

Risiko audit berdasarkan analisis total sampel tidak memiliki pengaruh yang signifikan terhadap imbalan jasa audit. Namun, hal ini berbeda ketika analisis dilakukan terhadap hasil pecah sampel. KAP Big-4 mempertimbangkan risiko audit pada saat menetapkan nilai imbalan suatu audit, sedangkan hal tersebut tidak dilakukan oleh KAP Non Big-4.

Semakin besar risiko audit seharusnya akan membuat pekerjaan audit menjadi semakin berat sebagaimana diungkapkan oleh Duellman et al. (2015). Big-4 akan senantiasa menjaga reputasi dengan cara menjaga kualitas auditnya. Kualitas audit Big-4 membuatnya pada posisi berhak untuk mendapatkan imbalan jasa audit yang lebih tinggi dari pada Non Big-4. Nilai imbalan jasa premium tersebut masih dapat dianggap wajar. Disamping itu, pekerjaan yang berisiko tinggi juga akan melibatkan sumber daya besar, baik dari segi kuantitas maupun kualitas (Kusharyanti, 2013), sehingga perhitungan imbalan jasa audit akan menjadi lebih tinggi dibandingkan dengan perusahaan dengan risiko audit rendah.

Risiko audit dapat dilihat dari perspektif auditor dalam menilai implementasi tata kelola yang baik (Good Corporate Governance (GCG)) oleh perusahaan. Yatim et al., (2006) mengungkapkan bahwa imbalan jasa audit akan dipengaruhi oleh efektivitas pengendalian internal perusahaan, yaitu semakin auditor tidak dapat mengandalkan sistem pengendalian internal perusahaan, maka semakin tinggi jumlah imbalan yang ditetapkan.

Pada implementasi GCG yang kurang efektif di Indonesia (Kaihatu, 2006), KAP maupun AP yang kurang cermat dalam memperhatikan kondisi tersebut tidak akan mempertimbangkan risiko audit yang tinggi pada saat menetapkan imbalan jasa audit- 
nya. Hal tersebut dapat membuat auditor tidak dapat mencapai kualitas audit yang maksimal karena pelaksanaan pro- sedur audit tidak mempertimbangkan tingginya risiko yang terjadi. Sebagai akibatnya, penyusunan program audit tidak dibuat untuk mengakomodasi keadaan tersebut. Jika hal ini selalu terjadi dan tidak digunakan untuk mempertimbangkan besarnya imbalan jasa audit oleh seluruh level KAP, maka pemberian jasa audit yang berkualitas menjadi tidak merata. Selain itu, kualitas audit menjadi identik dengan KAP level tertentu saja, yaitu Big-4. Berdasarkan data yang terdapat pada Tabel 2, perusahaan manufaktur yang diaudit oleh KAP Non Big-4 selama tahun 2013-2016 mencapai total 91 perusahaan, sedangkan Big-4 hanya sebesar 52 perusahaan. Oleh karena itu, perlu pengawasan lebih lanjut oleh organisasi profesi dan regulator dalam pelaksanaan audit berbasis RBA.

Hasil pengujian menunjukkan bahwa CFO berpengaruh positif terhadap imbalan jasa audit pada perusahaan yang diaudit oleh KAP Big-4. Kondisi ini menunjukkan hasil yang berbeda dengan hasil penelitian Corbella et al. (2015) yang menyatakan bahwa CFO tidak memiliki pengaruh terhadap imbalan jasa audit. Hasil menarik mengenai pengaruh $\mathrm{CFO}$ dapat dilihat pada pengujian tambahan. Lev terbukti berpengaruh signifikan positif terhadap imbalan jasa audit sebagaimana penelitian (Risheh dan Al-Saeed, 2014) terutama pada sampel keseluruhan dan Non Big-4. SALESGR berpengaruh signifikan positif terhadap imbalan jasa audit hanya pada perusahaan yang diaudit oleh KAP Non Big-4 sebagaimana hasil penelitian (Keane et al., 2012). Artinya, kelompok KAP ini mempertimbangkan meningkatnya pertumbuhan pendapatan auditee pada saat menetapkan imbalan jasa auditnya. Pengaruh ROA terhadap imbalan jasa audit pada penelitian ini sama dengan pada penelitian yang dilakukan oleh Huang et al. (2014) dan Charles et al. (2010). Hal ini menunjukkan bahwa kinerja perusahaan yang baik dapat menurunkan besarnya imbalan jasa audit, baik pada auditee yang diaudit oleh KAP Big4, maupun Non Big-4. Namun, Size tidak terbukti berpengaruh terhadap imbalan jasa audit.

Penelitian ini juga melakukan analisis tambahan dengan mengganti variabel dependen imbalan jasa audit (totrescaled) menjadi imbalan jasa audit abnormal (abnfees). Choi et al., (2010) mendefinisikan imbalan jasa audit abnormal adalah perbedaan antara imbalan aktual yang diterima dengan yang diharapkan oleh auditor pada tingkat normal, yaitu dapat lebih besar maupun lebih kecil.

Hasil analisis tambahan pada Tabel 4 menunjukkan hasil bahwa tenur KAP, rotasi AP dan KAP, kompleksitas perusahaan, dan risiko audit tidak berpengaruh signifikan terhadap imbalan jasa audit abnormal. Hal ini menunjukkan bahwa hasil hipotesis nol $\left(\mathrm{H}_{01}, \mathrm{H}_{02 a}\right.$, dan $\left.\mathrm{H}_{02 a}\right)$ adalah robust, sedangkan hipotesis akternatif $\left(\mathrm{H}_{3}\right.$ dan $\left.\mathrm{H}_{4}\right)$ tidak menunjukkan hasil yang sama.

Choi et al. (2010) mengasumsikan bahwa imbalan jasa abnormal dapat terjadi karena adanya hubungan istimewa antara auditor dan klien atau dengan kata lain hubungan istimewa tersebut terbentuk melalui masa penugasan yang relatif lama diantara keduanya. Kondisi tersebut tidak sesuai dengan hasil penelitian ini karena tenur audit tidak memengaruhi adanya imbalan jasa abnormal. Hal ini dapat terjadi karena KAP di Indonesia yang mengaudit perusahaan manufaktur telah menerapkan independensinya dalam menetapkan imbalan jasa suatu penugasan audit.

Kedua hasil pengujian mengenai rotasi KAP dan AP telah sesuai dengan hasil penelitian Corbella et al. (2015), namun yang berbeda adalah penetapan imbalan jasa audit di Indonesia tidak dipengaruhi oleh lamanya masa penugasan. Pada penelitian sebelumnya, pemberlakuan lowballing atas imbalan jasa audit akan tergantikan dengan alokasi imbalan jasa tersebut pada penugasan tahun berikutnya, sedangkan pada penelitian ini hal tersebut tidak terbukti. Oleh karena itu, 
hasil hipotesis $\mathrm{H}_{02 a}$ dan $\mathrm{H}_{02 \mathrm{~b}}$ memperkuat hasil hipotesis $\mathrm{H}_{01}$. Temuan menarik dalam permodelan tambahan ini adalah variabel CFO (arus kas operasi).

Tabel 4

Hasil Regresi Determinan Imbalan Jasa Audit Abnormal

\begin{tabular}{llll}
\hline \hline Variabel & Seluruh Sampel & KAP Big-4 & KAP Non Big-4 \\
\hline TKAP & $-2,921 \mathrm{E}-5$ & $-2,132 \mathrm{E}-5$ & $4,189 \mathrm{E}-5$ \\
RKAP & 0,000 & - & - \\
RAP & - & 0,000 & $-7,889 \mathrm{E}-5$ \\
Comp & 0,001 & 0,001 & 0,001 \\
Arisk & $1,448 \mathrm{E}-5$ & $-0,008$ & $-1,700 \mathrm{E}-5$ \\
Size & $9,992 \mathrm{E}-5$ & $-5,829 \mathrm{E}-5$ & 0,000 \\
CFO & $-0,002^{* * *}$ & $-0,014^{* *}$ & $-0,002^{* * *}$ \\
Lev & $0,001^{*}$ & $-0,002^{* * *}$ & 0,001 \\
SALESGR & 0,000 & $0,003^{*}$ & - \\
ROA & - & - & $0,008^{*}$ \\
Konstanta & 0,001 & 0,001 & 0,001 \\
Sampel & 139 & 49 & 90 \\
Prob > chi2 & 0,033 & 0,008 & 0,020 \\
Adj R & 0,064 & 0,260 & 0,114 \\
\hline
\end{tabular}

Sumber: Hasil Olah Data Peneliti (2019)

Hasil penelitian berbeda dengan hasil Permodelan 2 yang menunjukkan pengaruh signifikan positif. Dengan menggunakan proksi varibel dependen yang berbeda, $\mathrm{CFO}$ menunjukkan pengaruh signifikan negatif terhadap imbalan jasa audit abnormal, artinya semakin tinggi arus kas operasi suatu perusahaan berpengaruh pada semakin rendahnya penetapan imbalan jasa audit abnormal. Berbeda dengan penelitian Jung et al., (2016), hasil penelitian ini menunjukkan bahwa Bonding Theory dapat juga berlaku untuk nilai imbalan jasa di bawah nilai normalnya karena AP dan KAP melihat prospek keuangan perusahaan yang baik di masa mendatang. Prospek tersebut dapat dijadikan sebagai investasi bagi auditor untuk memberikan imbalan yang rendah dalam rangka mempertahankan keberlanjutan penugasan yang sama. Febrianto et al., (2017) berargumentasi bahwa secara logika auditee dengan tingkat kesejahterahan yang tinggi layak untuk dipertahankan dan lebih ekstrim lagi auditor bersedia untuk membubarkan KAP lama demi membentuk KAP baru agar supaya tetap dapat melakukan penugasan audit untuk auditee tersebut.
Variabel kontrol yang menunjukkan hasil yang sama (robust) dengan permodelan utama adalah Size dan Lev, sedangkan SALESGR dan ROA menunjukkan hasil yang berbeda. Berdasarkan hasil empiris tersebut, penelitian ini akan dijadikan pengantar bagi penelitian berikutnya untuk mengetahui determinan penentuan imbalan jasa audit abnormal, khususnya di Indonesia.

\section{SIMPULAN DAN SARAN}

Penelitian ini dilakukan untuk menganalisis apakah auditor di Indonesia telah menerapkan peraturan yang berlaku dalam menetapkan imbalan jasa auditnya, khususnya bagi perusahaan manufaktur yang terdaftar di BEI. Dua faktor, yaitu tenur audit dan rotasi audit, yang selama ini diperdebatkan keberadaannya dapat memengaruhi keputusan penetapan imbalan ternyata tidak terbukti dijadikan sebagai acuan oleh auditor. Hasil penelitian ini dapat dijadikan sebagai dukungan terhadap PP No 20 tahun 2015 yang menghapus rotasi KAP dan sekaligus menunjukkan bahwa indepedensi dalam penugasan audit dapat tetap 
terjaga dalam jangka waktu penugasan yang panjang pada KAP.

Kompleksitas perusahaan telah terbukti menjadi salah satu faktor utama yang dipertimbangkan oleh auditor saat menentukan imbalan jasa auditnya. Hasil penelitian ini menunjukkan semakin kompleks perusahaan akan mengakibatkan semakin rendahnya imbalan jasa audit. Perusahaan yang kompleks akan meningkatkan penggunaan TI untuk mengintegrasikan kebutuhan operasional dan pengawasannya. Selain itu, keberadaan anak perusahaan yang diaudit oleh KAP yang berbeda dengan induknya dapat menjadi alokasi pembebanan imbalan jasa audit yang terpisah. Penelitian ini memberikan bukti bahwa kompleksitas perusahaan tidak selalu menjadi dasar dalam penetapan imbalan jasa audit yang tinggi, khususnya pada sektor manufaktur di Indonesia.

Berbeda dengan kompleksitas, risiko audit tidak sepenuhnya dipergunakan sebagai pertimbangan oleh auditor perusahaan yang melakukan penugasan di sektor manufaktur di Indonesia. Hasil penelitian ini membuktikan hanya auditor yang bekerja pada KAP Big-4 yang akan menggunakan risiko audit dalam menghitung imbalan jasa auditnya. Situasi ini harus menjadi sorotan utama bagi organisasi profesi dan regulator karena standar audit dengan basis RBA telah diimplementasikan dan berlaku efektif sejak periode audit tahun 2013. Oleh karena itu, implementasi pendekatan audit berbasis risiko terhadap seluruh KAP di Indonesia perlu mendapatkan pengawasan yang berkelanjutan.

Penelitian ini juga menunjukkan variabel CFO, Lev, SALESGR, dan ROA memiliki arah pengaruh yang berbeda-beda terhadap imbalan jasa audit, sedangkan Size terbukti tidak memiliki pengaruh yang signifikan. Khusus variabel CFO, penelitian ini mengungkapkan hasil yang menarik, khususnya pada pengujian tambahan, yaitu adanya Bonding Theory di Indonesia.

Saran bagi penelitian berikutnya adalah menguji determinan imbalan jasa audit untuk sektor lain, selain sektor manufaktur. Pengujian juga dapat dikembangkan untuk mengetahui batas imbalan jasa audit normal dan abnormal bagi perusahaan yang terdaftar di BEI. Selain itu, penelitian yang berkenaan dengan penerapan RBA dapat terus dikembangkan mengingat hasil penelitian ini tidak menemukan adanya pengaruh serempak dalam penerapannya pada seluruh level KAP.

\section{DAFTAR PUSTAKA}

Al-Thuneibat, A. A., R. T. I. Al Issa, dan R. A. Ata Baker. 2011. Do audit tenure and firm size contribute to audit quality?: Empirical evidence from Jordan. Managerial Auditing Journal 26(4): 317334.

Anastasopoulos, N. P. dan M. P. Anastasopoulos. 2012. The evolutionary dynamics of audit. European Journal of Operational Research 216(2): 469-476.

Arens, A. A., R. J. Elder, M. S. Beasley, dan C. E. Hogan. 2017. Auditing and Assurance Services: Global Edition (sixteenth). Pearson Education Limited. England.

Ball, F., J. Tyler, dan P. Wells. 2015. Is audit quality impacted by auditor relationships? Journal of Contemporary Accounting and Economics 11(2): 166-181.

Bhattacharjee, S., M. J. Maletta, dan K. K. Moreno. 2017. Audit reviewers' judgments in multiple client audit environments. Behavioral Research in Accounting 29(2): 1-9.

Bryan, D. B. dan T. W. Mason. 2016. The influence of earnings management conducted through the use of accretive stock repurchases on audit fees. Advances in Accounting, Incorporating Advances in International Accounting 34: 99-109.

Bryan, D. B. dan T. W. Mason. 2017. Executive tournament incentives and audit fees. Advances in Accounting 37: 3045.

Cahan, S. F. dan J. Sun. 2015. The Effect of Audit Experience on Audit Fees and 
Audit Quality. Journal of Accounting, Auditing \& Finance 30(1): 78-100.

Cameran, M., J. R. Francis, A. Marra, dan A. Pettinicchio. 2015. Are there adverse consequences of mandatory auditor rotation? Evidence from the Italian experience. Auditing 34(1): 1-24.

Carcello, J. V. dan A. L. Nagy. 2004. Audit firm tenure and fraudulent financial reporting. Auditing 23(2): 55-69.

Charles, S. L., S. M. Glover, dan N. Y. Sharp. 2010. The association between financial reporting risk andaudit fees before and after the historic events surrounding SOX. AUDITING: A Journal of Practice $\mathcal{E}$ Theory 29(1): 15-39.

Choi, J., J. Kim, dan Y. Zang. 2010. Do Abnormally High Audit Fees Impair Audit Quality? Auditing: A Journal of Practice \& Theory 29(2): 115-140.

Collings, S. 2011. Interpretation and application of international standards on auditing. John Wiley \& Sons. United Kingdom.

Collings, S. J. 2011. Interpretation and Application of International Standards on Auditing. Wiley. United Kingdom.

Corbella, S., C. Florio, G. Gotti, dan S. A. Mastrolia. 2015. Audit firm rotation, audit fees and audit quality: The experience of Italian public companies. Journal of International Accounting, Auditing and Taxation 25: 46-66.

De Angelo, L. E. 1981. Auditor Size And Audit Quality. Journal of Accounting and Economics 3(May): 183-199.

de Villiers, C., D. Hay, dan Z. Zhang. 2013. Audit fee stickiness. Managerial Auditing Journal 29(1): 2-26.

Duellman, S., H. Hurwitz, dan Y. Sun. 2015. Journal of Contemporary Accounting \& Economics Managerial overconfidence and audit fees. Journal of Contemporary Accounting \& Economics 11(2): 148-165.

Ebrahim, A. 2010. Audit fee premium and auditor change: The effect of SarbanesOxley Act. Managerial Auditing Journal 25(2): 102-121.

El-Gammal, W. 2012. Determinants of Audit Fees: Evidence from Lebanon.
International Business Research 5(11): 136145.

Febrianto, R., F. Dini, D. Audina, Y. Yuskar, dan V. Juita. 2017. The Influence of Pseudo Auditor Rotation on Audit Quality : New Evidence The Influence of Pseudo Auditor Rotation on Audit Quality: New. Australasian Accounting, Business and Finance Journal 11(4): 71-85.

Geiger, M. A. dan K. Raghunandan. 2002. Auditor tenure and audit reporting failures. Auditing 21(1): 67-78.

Goddard, A. R., C. Masters, A. R. Goddard, dan C. Masters. 2006. Audit committees, Cadbury Code and audit fees: an empirical analysis of UK companies. Managerial Auditing Journal 15(7): 358371.

Grosse, M., N. Ma, dan T. Scott. 2018. Interim reviews and the association between partner rotations and audit fees. International Journal of Auditing (January): 116.

Habib, A., M. B. U. Bhuiyan, dan X. Sun. 2019. Audit partner busyness and cost of equity capital. International Journal of Auditing 23(1): 57-72.

Harindahyani, S. 2015. Realitas Materialitas Audit dalam Teori dan Praktik. Akuntansi Bisnis 8(1): 1-20.

Hassan, M., S. Hassan, A. Iqbal, dan M. F. A. Khan. 2014. Impact of Corporate Governance on Audit Fee: Empirical Evidence from Pakistan. World Applied Sciences Journal 30(5): 645-651.

Hassan, Y. M. 2016. Determinants of audit report lag: evidence from Palestine. Journal of Accounting in Emerging Economies 6(1): 13-32.

Hay, D. 2013. Further Evidence from MetaAnalysis of Audit Fee Research. International Journal of Auditing 17(2): 162-176.

Hayes, R., R. Dassen, A. Schilder, dan P. Wallage. 2014. An Introduction to International Standards on Auditing, Second Edition. 713.

Hayes, R., P. Wallage, dan H. Gortemaker. 2014. Principle of Auditing: An Intro- 
duction to International Standards on Auditing (third). Pearson Educated Limited. United Kingdom.

Hong, P. K. dan S. Hwang. 2018. Advances in Accounting Fair value disclosure of pension plan assets and audit fees. Advances in Accounting 41(January): 8896.

Huang, H. W., K. Raghunandan, dan D. Rama. 2009. Audit fees for initial audit engagements before and after sox. Auditing 28(1): 171-190.

Huang, T.-C., H.-W. Huang, dan C.-C. Lee. 2014. Corporate executive's gender and audit fees. Managerial Auditing Journal 29(6): 527-547.

IAPI. 2016a. Standar Profesional Akuntan Publik-Seri Prinsip Umum dan Tanggung Jawab. Salemba Empat. Jakarta.

IAPI. 2016b. Standar Profesional Akuntan Publik: Seri Penilaian Risiko dan Respons terhadap Risiko yang Dinilai. Salemba Empat. Jakarta.

Jensen, M. C. dan W. H. Meckling. 1976. Theory of the Firm: Managerial Behavior, Agency Costs and Ownership Structure. Economics Social Institutions: 163-231.

Ji, X.-D, W. Lu, dan W. Qu. 2018. Internal control risk and audit fees: Evidence from China. Journal of Contemporary Accounting and Economics 14(3): 266-287.

Jia, N. 2017. Tournament incentives and audit fees. Journal of Accounting and Public Policy, 36(5): 358-378.

Johnson, L. dan T. B. O. Keefe. 2015. The effect of tenure on auditor realization rates. Managerial Auditing Journal 30(3): 206-225.

Jubb, C. A., K. A. Houghton, dan S. Butterworth. 1996. Audit fee determinants: The plural nature of risk. Managerial Auditing Journal 11(3): 25-40.

Jung, S. J., B. J. Kim, dan J. R. Chung. 2016. The association between abnormal audit fees and audit quality after IFRS adoption Evidence from Korea. International Journal of Accounting and Information Management 24(3): 252-271.
Kaihatu, T. S. 2006. Good Corporate Governance dan Penerapannya di Indonesia Thomas. Ekonomi Manajemen 8(1): 1-9.

Keane, M. J., R. J. Elder, dan S. M. Albring. 2012. The effect of the type and number of internal control weaknesses and their remediation on audit fees. Review of Accounting and Finance 11(4): 377-399.

Krauß, P. dan H. Zülch. 2013. The Relation of Auditor Tenure To Audit Quality: Empirical Evidence From the German Audit Market. Journal of Governance and Regulation 2(1): 27-43.

Kusharyanti. 2013. Analysis of the factors determining the audit fee. Jounal of Economics, Business, and Accountancy Ventura 16(80): 147-160.

Larasati, D. A., M. C. Ratri, M. Nasih, dan I. Harymawan. 2019. Independent audit committee, risk management committee, and audit fees. Cogent Business and Management 6(1): 1-15.

Leidner, J. J. dan H. Lenz. 2017. Client's business risk, public-interest entities, and audit fees: The case of German credit institutions. International Journal of Auditing 21(3): 324-338.

Liu, H., L. Ma, dan P. Huang. 2015. When organizational complexity helps corporation improve its performance. Journal of Management Development 34(3): 340351.

Mazza, T. dan S. Azzali. 2018. Information Technology Controls Quality and Audit Fees: Evidence From Italy. Journal of Accounting, Auditing \& Finance 33(1): 123-146.

Mohammadrezaei, F. dan N. Mohd-saleh. 2017. Auditor switching and audit fee discounting: the Iranian experience. Asian Review of Accounting 25(3): 335360.

Ng, H. Y., P. C. Tronnes, dan L. Wong. 2018. Audit seasonality and pricing of audit services: Theory and evidence from a meta-analysis. Journal of Accounting Literature 40(November 2014): 16-28.

Okoye, E. I. dan S. I. Adeniyi. 2016. The Effect of Audit Tenure and Non-Audit Services 
on Auditors Negligence: A Study of Nigeria. International Journal of Accounting Research 2(8): 21-28.

Risheh, K. E. A. dan M. A. Al-Saeed. 2014. The Impact of IFRS Adoption on Audit Fees: Evidence from Jordan. Accounting and Management Information Systems 13(3): 520-536.

Rusmanto, T. dan S. Remond. 2015. Factors influencing audit fee in Indonesian Publicly Listed Companies applying GCG. Procedia - Social and Behavioral Sciences 172: 63-67.

Safriliana, R., B. Subroto, I. Subekti, dan A. F. Rahman. 2018. An Overview on Contracting Theory and Agency Theory: Determinants of Voluntary Public Accounting Firms Switching. KnE Social Sciences 3(10): 10-22.

Sinaga, E. A. dan S. Rachmawati. 2018. Besaran Fee Audit Pada Perusahaan Yang Terdaftar Di Bursa Efek Indonesia. Media Riset Akuntansi, Auditing \& Informasi 18(1): 19-34.

Stanley, J. D., D. M. Brandon, dan J. J. Mcmillan. 2015. Public Policy Does lowballing impair audit quality?
Evidence from client accruals surrounding analyst forecasts. Journal of Accounting and Public Policy 34(6): 625645.

United States General Accounting Office. 2003. Public Accounting Firms: Required Study On The Potential Effects Of Mandatory Audit Firm Rotation. Http:/Www.Gao.Gov/Assets/250/240736.

$P d f$.

Wan Hussin, W. N., H. M. Bamahros, dan S. N. Shukeri. 2018. Lead engagement partner workload, partner-client tenure and audit reporting lag: Evidence from Malaysia. Managerial Auditing Journal 33(3): 246-266.

Xie, Z., C. Cai, dan J. Ye. 2010. Abnormal Audit Fees and Audit Opinion - Further Evidence from China's Capital Market. China Journal of Accounting Research 3(1): 51-70.

Yatim, P., P. Kent, dan P. Clarkson. 2006. Governance structures, ethnicity, and audit fees of Malaysian listed firms. Managerial Auditing Journal 21(7): 757782. 